\title{
IMPACT OF FOREIGN DIRECT INVESTMENT ON ECONOMIC GROWTH OF NEPAL
}

\author{
Shiva Prasad Pokharel ${ }^{I^{*}}$ and Bishnu Prasad Pokharel ${ }^{2}$ \\ ${ }^{*}$ Associate Professor, Patan Multiple Campus, Lalitpur, Faculty of Management, TU \\ ${ }^{2}$ Faculty of Nepal Open University, Lalitpur \\ *Corresponding author
}

\begin{abstract}
This paper aims to investigate the impact of Foreign Direct Investment (FDI) on the economic growth of Nepal for the period 2008/09 to 2017/18 A.D. yearly data. It evaluated the Gross Domestic Product (GDP) performance and the trends of FDI and Gross Fix Capital Formation (GFCF) in Nepal. To demonstrate the relationship between Nepalese Gross Domestic Product (GDP) and Foreign Direct Investment (FDI) and Gross Fix Capital Formation (GFCF) Multiple-Regression-Model has been applied along with various econometrics techniques such as Unit-Root Test, Granger-Causality Test and Ordinary Least Square (OLS). GDP in this model is used as dependent variable whereas FDI and GFCF are measured as independent variables. According to the results, Unit Root Test indicated that all the variables included in the model were not stationary at level except FDI, whereas GDP and GFCF are stationary at first difference. The model is overall significant with the positive and significant relationship of GDP, FDI and GFCF. Result also indicate a good fit for the model with $\mathrm{R} 2=86 \%$. The Granger Causality Test revealed that there was no causality between the variables since all p-value obtained are more than $5 \%$. Based on the empirical result of this paper, policy recommendation proposed that for Nepal to generate more foreign direct investment, hard work should be made at solving problems of government involvement in business; relative closed economy; corruption; weak public institutions; and poor external image, and political instability.
\end{abstract}

Keywords: GDP - FDI - GFCF - Nepali - economy

\section{INTRODUCTION}

FDI is a key determinant for the success of rapid economic growth of any country. It is a process of acquiring long lasting effective investment for operating activities through foreign channels. In general, FDI is defined as an inflow of cash and non cash in to the host country from foreign 
lands. It contributes notable improvement to the economic growth of the poor countries. It influences both tangible and intangible properties such as production, export, import, balance of payment, employment, income, price and common welfare of the host country. The main achievement of FDI inflows is that it may result in importing advanced technology, skills, training, knowledge, capital and significant properties. In addition, the host country may get economic benefit from the spillover effect of multinational companies (MNCS). For developing countries, FDI is one of the most effective techniques to maintain cordial relationship with the rest of the world (Hossain 2012). Foreign Direct Investments are the net flows of investment to acquire a lasting management interest in an enterprise operating in an economy other than that of investors. It is sum of equity capital, reinvestment of earnings, other long term capital and short term capital as shown in the balance of payments (World Bank 2012).

Nepal is a virgin land for affiliates of FDI. It has abundant labor and high accessibility of natural resources. To attract FDI, Nepal should manage and control the business environment. Such factors influencing multinational company's decisions in countries include political stability, business friendly regulatory environment, infrastructure, assess to land and low tax rate. In brief, FDI does not only provide benefit to host country's economy but also provides benefits to the home country like expansion, diversification and growth of market share as well as influence national economy to international economy. Pyakurel (2074) states that country own unique advantages are opportunities for attracting FDI on contry's prosperity.

Nepal has become an emerging economy for foreign investors. Many investment opportunities in various sectors like tourism, hydropower, medical tourism and hospitality sectors etc. on the other hand, government of Nepal should identify and rectify existing weakness in overall administrative mechanism to attract foreign investors. FDI of Nepal is not aloof from its inherent challenges though that need to be timely addressed with prudent measures (Pyakurel 2074).

More over corruption, occasional political violence, inefficient bureaucracy, poor infrastructure, unskilled work force, and reduced transparency in its legal and regulatory system works as investment deterrents. In addition, climate hazards also pose a threat to FDI flows. India, China and USA are the leading investors of Nepal as per FDI Flows.

The unique feature of FDI is that it brings in a package of resourcescapital, technology, skills, management know how and marketing capabilities- together with production activities to a host country. Affiliates 
of host country optimize profit through proper mobilization of these resources and capabilities.

Foreign Direct Investment can generate not only products for domestic consumption or for export, income and employment but also linkages and spillovers that bolster the capabilities of domestic firms and human resources, contributing to capacity building and accelerated growth in the host economy. Furthermore, FDI has positive impact on GDP which result also revealed in the study of (Sokang 2018).

\section{RESEARCH METHODOLOGY}

The purpose of this research paper is to examine the impact of FDI inflow on the economic growth of Nepalese Gross Domestic Product (GDP) and the relationship between Gross Fix Capital Formation (GFCF) and GDP. Study covers the time period from 2008/09-2017/18. The yearly data obtained from Nepal Rastra Bank (NRB) and economic survey which is considered as an authentic source of data collection. To examine the relation of Nepal's GDP with FDI and (GFCF), the following theoretical model is used.

$$
\mathrm{GDP}=\mathrm{F}(\mathrm{FDI} \text { and GFCF) }
$$

The hub intention of the paper is to study the effect of FDI on GDP of Nepal. The trend of foreign Direct Investment inflows is also observed with relevance to GDP growth and GFCF. To examine the relation of Nepal's GDP with FDI and GFCF, the following multiple regression model is used,

$$
\mathrm{GDP}=\alpha+\beta 1 \mathrm{FDI}+\beta 2 \mathrm{GFCF}+\mu
$$

Where,

FDI $=$ Foreign Direct Investment

GDP $=$ Gross Domestic Product

GFCF $=$ Gross Fix Capital Formation

Level of Significant: 5 to 10 percent

\section{Method of data analysis}

In analyzing the dataset the following tests are expected to be employed. Unit root test for stationary, Augmented Dickey-Fuller Test (ADF, Ordinary Least Square (OLS) method, in order to determine the presence of the relationship among variables and its direction we applied the model suggested by (Said, Elias, Ouassou, Idir, Rachdi \& Mustapha 2015). His study reveals "GDP does not Grange cause FDI and vice-versa". The study used IBM SPSS 20 as well as E-views 6 software to analyze data. 


\section{EMPIRICAL RESULTS}

\section{Descriptive statistic}

The Multiple Regression Model was run on SPSS to find out the Impact of FDI and GFCF on the Gross Domestic Product of Nepal. In this multiple regression model, GDP is used as dependent variable whereas FDI and GFCF are defined as independent variables. To estimate the effect of FDI on GDP of Nepal, Multiple Regression Model is applied over the period of 2008/09 to 2017/18 Annually. Descriptive statistics of GDP, FDI and GFCF are as follows. The Table 1 showed a summary of the descriptive statistic for the three variables included in this study GDP, FDI, and GFCF. The table contains the mean, standard deviation, minimum and maximum for 10 observations covering the period 2008/09 to 2017/18 annually.

\section{Measures the dependent variable (GDP)}

In this study we used GDP as a dependent indicator in the Multiple Regression Model. Annually data covers the period from 2008/09 $-2017 / 18$ and it is taken from economic survey (2019). GDP measured in Million NPR. It is used as dependent variable. The result from descriptive statistic indicates that Nepalese real GDP recorded 5.85408 Million NPR. The minimum value of real GDP was 5.770931 Million NPR, while the maximum value was 5.945369 Million NPR.

Table 1: Descriptive statistics

\begin{tabular}{lrrr}
\hline & Log GDP & Log FDI & Log GFCF \\
\hline Mean & 5.854080 & 3.768749 & 5.194810 \\
Median & 5.856457 & 3.790539 & 5.167770 \\
Maximum & 5.945369 & 4.190612 & 5.434361 \\
Minimum & 5.770931 & 3.262214 & 5.039251 \\
Std. Deviation & 0.056431 & 0.302789 & 0.129471 \\
\hline
\end{tabular}

\section{Measures the independent variable (FDI)}

We used FDI as an independent growth in Multiple Regression Model. Annual data cover the period from 2008/09-2017/18 obtained from Economic Survey (2019). FDI measured in Millions of NPR. The finding showed that Nepalese real FDI inflow recorded 3.768749 Millions NPR. The Minimum value was 3.262214 Million NPR, while Maximum value recorded 4.190612 Million NPR. 


\section{Measures of independent variable (GFCF)}

We used GFCF as an independent growth in Multiple Regression Model. Yearly data cover the period from 2008/09-2017/18 obtained from Economic Survey. GFCF measured in Millions of NPR. The finding revealed that Nepalese real GFCF was 5.19481 Million NPR. The Minimum value was 5.039251 Million NPR, while Maximum value recorded 5.434361 Million NPR.

\section{Augmented Dickey-Fuller (ADF) unit root test}

The unit root test has been applied to check whether the variables are stationary or not. The test carried out through ADF method as suggested by Engel and Granger (1987). The ADF analysis carried at both level and difference. The null hypothesis in ADF test is that there is presence of unit root. The result of test is indicating in Table 2 .

Table 2: Augmented Dickey-Fullers (ADF)

\begin{tabular}{lrrr}
\hline Variables & Levels data & First differences & Status \\
\hline LOG GDP & 0.452219 & -2.8194071 & $(1)$ \\
LOG FDI & -3.056340 & -6.6273441 & $(0)$ \\
LOG GFCF & -1.209058 & -6.5921871 & $(1)$ \\
\hline
\end{tabular}

$1 \%$ Critical Value -3.525619

\section{Interpretation of unit root test result}

The result of Unit Root Test indicated that all the variables included in the model were not stationary at level except FDI. That can be seen through comparing the critical value with the ADF value, when the critical value is greater than $\mathrm{ADF}$ value meaning that the variable is not stationary. However, when the critical value of the variables is less than the ADF value the variable is stationary.

\section{The Granger causality test}

Table 3: Granger causality test

\begin{tabular}{lrrr}
\hline Null hypothesis: & Obs & F-Statistic & Prob. \\
\hline LOGFDI does not granger cause LOGGDP & \multirow{2}{*}{10} & 0.11689 & 0.8898 \\
LOG GDP does not granger cause LOGFDI & & 0.35370 & 0.7033 \\
\hline
\end{tabular}

To explain the granger causality test, we often asked questions such as "is GDP that causes FDI or is FDI that causes GDP?" We test for the absence of Granger causality by estimating the following VAR model: 


$$
\begin{aligned}
& \mathrm{GDP}=\Sigma \alpha ! \text { FDlt-3 }+\Sigma \beta \mathrm{j} \text { GDPt-3+ U1t } \\
& \mathrm{FD} 1=\Sigma \lambda \text { FDIt } 3+\Sigma \delta \text { iGDPt }-3+\mathrm{U} 2 \mathrm{t}
\end{aligned}
$$

$\alpha, \beta, \lambda$ and $\delta$ are parameters to be estimated, and Ult and $\mathrm{U} 2 \mathrm{t}$ are the error term.

Granger causality test was applied in order to determine the presence of the relationship among variables and its direction (Granger, 1969 ) is carried out using E-views 6. The findings of Granger Causality Test between FDI and GDP indicated in the following Table 3. The result in Table 3 shows that we cannot reject the null hypothesis, which means that GDP does not Grange cause FDI and vice-versa. Therefore, there was no causality between FDI and GDP of Nepal since all P-value is greater than $5 \%$.

\section{Ordinary least square (OLS)}

Table 4: Summary of OLS results GDP, FDI and GFCF

\begin{tabular}{rrrrrr}
\hline Country & Variables & Coefficient & P-Value & F-Statistics & R squire \\
\hline Nepal & Log FDI & .376 & .000 & 39.422 & 0.868 \\
& Log GFCF & .026 & .354 & & \\
\hline
\end{tabular}

$5 \%$ Critical Value -2.902953

$10 \%$ Critical Value -2.588902

OLS method has applied in this study. The summary of the test indicated that the model of the study is well fitted. All the variables in the model are statistically significant. The coefficient of the constant variable recorded 3.84 which indicate a positive relationship between the constant parameter and the Gross Domestic Product. Although, the constant parameter has no significant effect on the model rather than reflecting the value of GDP when other independent variables are help constant. The summary of OLS result showed in the above Table 4.

\section{Interpretation of OLS result}

The empirical results are presented by the above table. The slope coefficients of the both inputs (FDI) and (GFCF) in Multiple Regression Analyses have positive impact on GDP. If one percent change in FDI occurs, it will bring about $0.376 \%$ change in GDP and 1 percent change in GFCF will bring $0.026 \%$ change in GDP by holding other variables constant. Estimates FDI is highly significant whereas GFCF is insignificant. As the value of $F$ is high i.e., 39.422 and the value of $P$ is so small i.e., 0.000 we can deduce that model is overall very much significant and the results are not by chance. The $\mathrm{r}$-square of this model is 0.86 that means only $14 \%$ 
variation in the model is unexplained by FDI and GFCF whereas remaining variation $(86 \%)$ is explained by FDI and GDP.

\section{DISCUSSION AND CONCLUSION}

The main objective of this study is to investigate the impact of Foreign Direct Investment (FDI) on the economic growth of Nepal for the period 2008/09 to 2017/18. In an economy, direct investment is suggestive of a positive trend of investment which ultimately translates in increase in GDP and economic growth of the country. This can also be proved from the findings of this research that increasing trend of FDI also increases the GDP of the country which result is consistency with the result of (Said et al., 2015). Moreover, the model is overall significant with the positive and significant association of GDP and FDI while a negative and insignificant relationship found between GDP and GFCF which is the consistency result with (Gudaro, Chhapra, \& Sheikh, 2012). The Granger Causality test indicates no causality between GDP and FDI in the period under investigation. The significance of FDI in generating the target growth rate in Nepal may be restricted by the level of infrastructure, business environment, Economic reform, and political stability. Our finding indicate that contribution of GFCF is very poor in the model as well as insignificant which reflect the poor investment in infrastructure development in study period for fixed capital formation which is constancy with the result of Khan (2015) as per him FDI inflows exerted positive impact on economic growth in the short-run and the long-run if the domestic financial system has achieved a certain minimum-level development. Finding of the study on Spanish circumstances, the results are robust and clear about the yield that there is no evidence for FDI to stimulate economic growth which is the inconsistency result with the finding (Carbonell \& Werner, 2018) Whereas, Isaac, John, and John (2017) revealed that percentage increase in China's FDI stock in Africa significantly increases Africa's gross domestic product all things being equal and also finds that a causal link exists between GDP growth in Africa and China's FDI and the nature of causality is unidirectional is the consistency with the result. The results of the study of Jordan show that FDI affect human capital indirectly through gross domestic output which is also the homogeneity with the finding of this study (Mishal \& Abulaila 2007).

\section{REFERENCES}

Bank, N. R. (2018). Annual Report. Kathmandu, Nepal: Nepal Rastra Bank. Bank, W. (2012). The World Bank Annual Report. Washington, DC.: World Bank. 
Carbonell, J. B. \& Werner, R. A. (2018). Does foreign direct investment generate economic growth? A new empirical approach applied to Spain. Economic Geography, 94(4): 425-456.

GoN, (2019). Economic Survey. Kathmandu, Nepal: Government of Nepal, Ministry of Finance.

Granger, C. W. (1969). Econometric models and cross-spectral methods. Econometrica, 37(3): 424-438.

Gudaro, A. M., Chhapra, I. U. \& Sheikh, S. A. (2012). Impact of foreign direct investment on economic growth: A case study of Pakistan. Journal of Management and Social Sciences, 8(2): 22-30.

Hossain, M. K. (2012). Measuring the impact of BRAC microfinance operations: A case study of a village. International Buseness Research, 5(4): 112 - 123.

Isaac, D., John, A. \& John, O.-A. (2017). Effect of Chinese foreign direct investment on economic growth in Africa. Journal of Chinese Economic and Foreign Trade Studies, 10(2): 162-171.

Khan, M. A. (2015). Foreign direct investment and economic growth: The role of domestic financial sector. Islamabad: PIDE Working Papers.

Mishal, Z. \& Abulaila, Z. (2007). The impact of foreign direct investment and imports on economic growth: The case of Jordan. Journal of Economic and Administrative Sciences, 23(1): 1-31.

Ould, L. (2015). An investigation of the impact of foreign direct investment on economic growth: A case study of Mauritania. International Journal of Economics \& Management, 4(2): 224.

Pyakurel, B. (2074). Foreign direct investment in Nepal. NUTA JOURNAL, 5(1\&2): 48-55.

Said, O., Elias, Ouassou, Idir, Rachdi \& Mustapha. (2015). Functional statistics and applications. Switzerland: Springer International Publishing.

Sokang, K. (2018). The impact of foreign direct investment on the economic growth in Cambodia: Empirical evidence. International Journal of Innovation and Economic Development, 4(5): 31-38. 